Article

\title{
Evaluations of the Spitzenkandidaten: The Role of Information and News Exposure in Citizens' Preference Formation
}

\author{
Katjana Gattermann ${ }^{1,2, *}$, Claes H. de Vreese ${ }^{1}$ and Wouter van der Brug ${ }^{3}$ \\ ${ }^{1}$ Amsterdam School of Communication Research, University of Amsterdam, 1018 WV Amsterdam, The Netherlands; \\ E-Mail: k.gattermann@uva.nl (K.G.), C.H.deVreese@uva.nl (C.H.V.) \\ ${ }^{2}$ Amsterdam Centre for Contemporary European Studies, University of Amsterdam, 1018 WV Amsterdam, \\ The Netherlands \\ ${ }^{3}$ Department of Political Science, University of Amsterdam, 1018 WV Amsterdam, The Netherlands; \\ E-Mail: W.vanderBrug@uva.nl \\ * Corresponding author
}

Submitted: 2 October 2015 | Accepted: 18 December 2015 | Published: 29 February 2016

\begin{abstract}
The 2014 European Parliament (EP) elections were characterised by a novel element in European Union (EU) politics. For the first time, the major European party families put forward top candidates for President of the European Commission, the so-called Spitzenkandidaten. This paper tests whether this innovation had the potential to-at least partiallyalleviate the alleged accountability deficit. We rely on original survey data to assess citizens' preferences for each of the main Spitzenkandidaten: Jean-Claude Juncker, Martin Schulz, and Guy Verhofstadt. Our research is guided by three questions: what explains whether citizens formulate a preference for a certain Spitzenkandidat? Which factors are responsible for variations in such preferences? And, are these explanations moderated by citizens' political awareness? We show that three factors enable citizens to formulate a preference for the Spitzenkandidaten: news exposure, general EU political information, and campaign-specific information about the Spitzenkandidaten. Furthermore, we demonstrate that only the most knowledgeable citizens are able to use party cues in their evaluations of the Spitzenkandidaten. The implications of our findings are discussed with reference to the EU's democratic deficit debate.
\end{abstract}

\section{Keywords}

candidate evaluations; European Parliament elections; European Union politics; personalization of politics; political behaviour

\section{Issue}

This article is part of the issue "How Different Were the European Elections of 2014?", edited by Wouter van der Brug, Katjana Gattermann and Claes de Vreese (University of Amsterdam, The Netherlands).

(C) 2016 by the authors; licensee Cogitatio (Lisbon, Portugal). This article is licensed under a Creative Commons Attribution 4.0 International License (CC BY).

\section{Introduction}

The 2014 European Parliament (EP) elections brought about a novelty: the major European party families nominated top candidates for President of the European Commission, the so-called Spitzenkandidaten. Up until then, the European Council nominated candidates for Commission President. By making the Presidency dependent on the outcome of the elections, executive power was-indirectly-at stake. We explore fundamental questions relating to this novelty: first, what explains whether citizens formulate a preference for a Spitzenkandidat? Second, which factors are responsible for variations in such preferences? And third, are these explanations moderated by citizens' political awareness?

We situate our study in extant research on EP elections. This literature traditionally characterises these elections as being second-order national elections, 
which tend to be dominated by domestic politics. Compared to national elections, they display more signs of sincere voting and provide more opportunity to express discontent because no executive power has been at stake thus far. As a consequence, turnout is generally lower than in national elections, smaller and opposition parties tend to gain votes at the expense of government and larger parties, and radical, often Eurosceptic parties at the left and right ends of the spectrum do relatively well (e.g., Hix \& Marsh, 2011; Reif \& Schmitt, 1980; Van der Eijk, Franklin, \& Marsh, 1996). ${ }^{1}$

In an attempt to change the 'second-order nature' of EP elections, the novel Spitzenkandidat element was introduced in 2014. Moreover, it sought to address concerns about the EU's democratic deficit which, among other things, has thus far been reflected in the lack of opportunities for citizens to determine the composition of the EU executive (Føllesdal \& Hix, 2006). Hobolt and Tilley (2014) argue further that the EU suffers from an accountability deficit because citizens are not provided with sufficient information and opportunity to hold EU politicians accountable in EP elections. The Spitzenkandidaten campaigns had the potential to change this lack of information available to EU citizens because by nominating top candidates, the EP political groups sought to raise the awareness of and interest in the elections among European citizens ${ }^{2}$.

Most of the embryonic research on the role of Spitzenkandidaten has focused on the question whether and how their campaigns influenced citizens' interest in the EU elections (e.g., Hobolt, 2014), whether it motivated people to participate in those elections (Schmitt, Hobolt, \& Popa, 2015), and how their participation in televised debates influenced attitudes towards the EU (Maier, Rittberger, \& Faas, 2016). Our study contributes to this field by focusing on the relationship between political information and attitudes towards Spitzenkandidaten. Our study differs fundamentally from the other studies, in the sense that attitudes towards these Spitzenkandidaten represent the explanandum; in particular we explore citizens' preferences with regard to the Spitzenkandidaten.

To do this, we rely on original survey data as part of a four-wave online panel study conducted in the Netherlands in the context of the EP elections (De Vreese, Azrout, \& Möller, 2014). In the third wave of the panel survey, which was fielded in April 2014, i.e. one month prior to Election Day, we asked respondents to indicate their preferences for the three main Spitzenkandi-

${ }^{1}$ However, research on individual-level voter behaviour also suggests that strategic considerations play a role as well (e.g., Boomgaarden, Johann, \& Kritzinger, 2016; Carrubba \& Timpone, 2005; Clark \& Rohrschneider, 2009; Giebler \& Wagner, 2015).

2 See the EP's resolution of 22 November 2012 (2012/2829 (RSP)). daten, Guy Verhofstadt, Martin Schulz, and JeanClaude Juncker. ${ }^{3}$ Our research is guided by three questions: first, what explains whether citizens formulate a preference for a certain Spitzenkandidat? Second, which factors are responsible for variations in such preferences? And, third, to what extent are the effects of these different factors moderated by political awareness, which Zaller (1992, p. 21) defines as 'the extent to which an individual pays attention to politics and understands what he or she has encountered' (emphasis in the original). Our results show that news exposure as well as having general EU political information and campaign-specific information about the Spitzenkandidaten are important pre-conditions for citizens to formulate a preference for each of the Spitzenkandidaten. Moreover, knowledgeable citizens are able to use left/right and national party preferences as 'cues' to form their attitudes towards the specific candidates. These findings have important theoretical and political implications which we discuss in the conclusion.

\section{Expressing Preferences for Spitzenkandidaten}

Political awareness is likely to represent a crucial precondition enabling citizens to express their preferences for the Spitzenkandidaten. Zaller (1992, p. 21) argues that news exposure is important, but not sufficient for voters to formulate opinions. Citizens also need to have factual information at hand in order to make an informed choice at the polls. In the following discussion, we thus distinguish between news exposure and the extent to which citizens have political information about the EU, and the Spitzenkandidaten in particular.

Existing research has shown that information about the EU, its institutions and politicians is widely available to citizens. News coverage during EP election campaigns has become more comprehensive in recent years (Boomgaarden \& De Vreese, 2016; De Vreese, Banducci, Semetko, \& Boomgaarden, 2006; Schuck, Xezonakis, Elenbaas, Banducci, \& De Vreese, 2011) and the EP as well as individual members (MEPs) receive regular broadsheet coverage during non-election times (Gattermann, 2013; Gattermann \& Vasilopoulou, 2015). Furthermore, research on the personalization of politics suggests that individual politicians (e.g., Langer, 2007; Rahat \& Sheafer, 2007) and leaders in particular (e.g., Boumans, Boomgaarden, \& Vliegenthart, 2013) receive increasingly more news attention at the ex-

\footnotetext{
${ }^{3}$ Former Belgian Prime Minister Verhofstadt was put forward by the Alliance of Liberals and Democrats for Europe (ALDE) on February 1, 2014; the incumbent EP President and German politician Schulz was chosen by the Progressive Alliance of Socialists and Democrats (S\&D) as their main contender on March 1, 2014; and Juncker, former Prime Minister of Luxembourg and former President of the Eurogroup, was nominated by the European People's Party (EPP) on March 7, 2014 (see also Put, Van Hecke, Cunningham, \& Wolfs, 2016).
} 
pense of political parties and institutions. We still know little about such trends in EU politics (Gattermann, 2015), however, we may expect that the personalization of the EP election campaign would generate more media attention (e.g., see Schulze, 2016), especially since the Spitzenkandidaten had 'substantial presence on the ground' through their direct campaigns across Europe (Schmitt et al., 2015, p. 351) and their participation in several pan-European televised debates.

Survey research has shown that news exposure can have positive effects on the intentions to turn out to vote (e.g., Aarts \& Semetko, 2003; De Vreese \& Boomgaarden, 2006; De Vreese \& Tobiasen, 2007; SchmittBeck \& Mackenrodt, 2010; Schuck, Vliegenthart, \& De Vreese, 2016). We consider two interrelated ways in which news exposure affects turnout. First, media attention would increase citizens' perceptions that there is something important at stake, and secondly, news exposure informs people about what is at stake. To the extent that this second mechanism applies, we would expect that those citizens who are regularly exposed to news coverage will be better able to express a preference for a certain Spitzenkandidat.

Some argue that these effects would be conditional upon the type of content. Aarts and Semetko (2003), for instance, show that exposure to public television had a positive effect on an individual's decision to participate in general elections, while private television caused negative effects. Similarly, De Vreese and Tobiasen (2007) find that newspaper reading and watching news on public television programmes increased the likelihood of voters to turn out in the 2004 EP elections. Other research suggests that soft-news and nonquality outlets may also increase awareness, such as knowledge about 2004 US primary campaigns, which was positively influenced by exposure to US Democratic candidates' appearances in late-night programmes and comedy shows (Brewer \& Cao, 2006). During the 2009 EU elections, Banducci, Giebler and Kritzinger (2015) even found that exposure to non-quality news content had a stronger relationship with knowledge about party positions in EU elections than exposure to quality news. This is slightly surprising because research has shown that during EP elections European affairs are more visible in quality media compared to non-quality outlets (e.g., De Vreese et al., 2006). Conversely, non-quality outlets are more likely to present news in terms of personalization, that is to say, shifting away from issues to individuals, as it goes hand in hand with the news value of human interest. Jebril, Albæk and De Vreese (2013) indeed found that exposure to personalization content has a negative effect on political cynicism, albeit only for those who are generally less interested in politics. We thus expect that news exposure to both quality and non-quality news content has a significant, positive effect on the preference for a Spitzenkandidat.
H1a: The higher their news exposure, the more likely citizens are to formulate a preference for the Spitzenkandidaten.

However, exposure to information does not necessarily infer that citizens are fully aware of that information. They also have to process the information that is available to them. We apply the definition of political awareness by Zaller (1992, p 21) and consider knowledge as an indicator of having factual information. In line with much of the extant literature, we distinguish between general political information and campaign-specific information (e.g., Chaffee, Zhao, \& Leshner, 1994; Converse, 1962; Nadeau, Nevitte, Gidengil, \& Blais, 2008). General political information can be understood as information that has been available prior to the election campaigns, such as general differences between political parties, whereas campaign-specific information relates to the candidates themselves and their different policy positions (Chaffee et al., 1994, p. 306). ${ }^{4}$

Political information is also relevant for electoral decisions. Nadeau et al. (2008) show that those with high levels of general information are less likely to change their vote choice over the course of the campaigns, while campaign-specific information increases the likelihood of volatility. In the EU context, information is also key to opinion formation and vote choice. Elenbaas, De Vreese, Boomgaarden and Schuck (2012) show that utilitarian performance judgements are positively influenced by acquisition of performance-specific information, while general political knowledge does not play a direct role. Regarding voter behaviour in EU elections, De Vries, Van der Brug, Van Egmond and Van der Eijk (2011) find that general political knowledge positively affects EU issue voting, that is, the extent to which vote choice is being influenced by attitudes towards EU integration (De Vries, 2007).

EU politics are quite complex and do not necessarily resemble political processes in the domestic political system with which citizens are more familiar. This complexity is also apparent in the Spitzenkandidaten nomination: it was not clear during the campaigns whether and how the election outcome would translate into a position in the executive office. General information about EU politics is thus likely to be imperative for the ability of citizens to formulate preferences for the Spitzenkandidaten.

H1b: The more comprehensive their general political information about the EU, the more likely are citizens to formulate preferences for the Spitzenkandidaten.

\footnotetext{
${ }^{4}$ These two types of information correlate highly; those who have high levels of general political information available are also more likely to have more campaign-specific information at hand (e.g., Converse, 1962, p. 586).
} 
Turning to campaign-specific information, Gelman and King (1993) as well as Arcenaux (2006) argue that campaigns enable voters, through learning, to form 'enlightened preferences' for parties or candidates. Evidence suggests that this is also case for EU elections and referendums. Although De Vries et al. (2011) do not specifically test the effects of campaign-specific information at the individual level, they find that the context of higher media attention towards the EU and more party contestation during the elections increases the extent of EU issue voting. Furthermore, Hobolt and Wittrock (2011) show that voters with additional information about the EU positions of parties are more likely to base their vote choice on their preferences for EU integration (see also Hobolt, 2007).

With particular view to the Spitzenkandidaten nomination, the difficulty for voters lay in linking the candidates with those national parties that indirectly supported the lead candidate. In European elections, voters are unable to vote for a European party group directly, but elect representatives of national parties. In other words, Dutch voters were required to understand that a vote for the Christian Democrats (CDA) means an indirect support for the EPP and therewith also their lead candidate Jean-Claude Juncker. We may thus also expect that campaign-specific information qualifies citizens to formulate a preference for a Spitzenkandidat. Conversely, those who only have very little or no information are unlikely to be able to formulate a preference since they are unlikely to have made the connection between their vote for a national party and the Spitzenkandidaten.

H1c: Citizens are more likely to formulate a preference for the Spitzenkandidaten, the more campaign-specific information they have about them.

\section{Explaining Variations in Preferences for Spitzenkandidaten}

Having discussed our hypotheses regarding the first main question-what explains whether citizens formulate preferences for the Spitzenkandidaten-we now turn to the question what explains variations in such perceptions. Why would someone have a high preference for Schulz and dislike Verhofstadt? To answer this question, it is important to realize that at the start of the campaign the Spitzenkandidaten were hardly known outside their home countries. This raises the question, on what basis can citizens form their judgments of candidates for whom they know very little?

The relevant literature on voting behaviour shows that voters who lack 'encyclopaedic' information about parties or candidates can often make use of 'cues', or 'information shortcuts', which help them form their political preferences (e.g., Lupia, 1994; Toka, 2008).
Electoral research since the 1950s has repeatedly demonstrated that most voters have limited political knowledge (e.g., Campbell, Converse, Miller, \& Stokes, 1960; Delli Carpini \& Keeter, 1996). Yet, even those with limited knowledge are often able to make a reasoned choice if they use the little information that they have in a smart way (e.g., Popkin, 1991; Sniderman, 2000; Van der Brug, 1999), though the choices derived from these cues may often be suboptimal (e.g., Lau \& Redlawsk, 2001). In the absence of concrete knowledge about the issue positions of parties, citizens often rely on more general information they have about these parties, such as their left-right positions (e.g., Downs, 1957; Van der Eijk \& Franklin, 1996). Other important heuristics that have been identified are partisan information (e.g., Hobolt, 2007), campaign events (Lodge, Steenbergen, \& Brau, 1995), and perceptions of corruption (Toka, 2008).

In the context of EP elections it has been well established that voters, lacking information about European affairs, often take cues from national politics (Anderson, 1998). This is so frequent that European elections have even been labelled second-order national elections (e.g., Reif \& Schmitt, 1980; Schmitt \& Thomassen, 1999; Van der Brug \& Van der Eijk, 2007). There are various cues that voters can take from national politics, such as their satisfaction with the incumbent parties, scandals, economic developments, evaluations of party leaders, preferences for national parties, or ideological similarities. In this paper we focus only on these latter two aspects: national party preferences and ideological distance.

If voters have little information about the Spitzenkandidaten, we believe it makes sense for them to rely on these two cues. A Dutch person with a strong preference for the national CDA could use this as a cue to evaluate Junker of the EPP. If she dislikes the Dutch Social Democrats (PvdA), she could equally use this as a cue to derive a less positive evaluation of the social democratic Spitzenkandidat Schulz. Another cue that voters can use to evaluate the Spitzenkandidaten would be through the lens of ideology. If someone is left-leaning and thus perceives himself to be ideologically close to the PvdA and far from the VVD (liberals), he might use this as a heuristic to evaluate Schulz more positively than Verhofstadt. We derive the following two hypotheses:

H2a: National party preferences will positively affect the preferences of the Spitzenkandidat of the affiliated party group.

H3a: Ideological distances to the affiliated national party will have a negative effect on preferences for the Spitzenkandidaten.

However, the extent to which voters are able to use these national party preferences as a heuristic from 
which to derive information about the candidates will depend crucially on their pre-existing knowledge. This argument is based on Zaller (1992) who asserts by his 'reception axiom' that those who are politically aware are better able to evaluate and therefore make use of the cues they receive. It has been well established in the literature that the extent of issue voting increases with the knowledge about party positions (e.g., Alvarez, 1997; De Vries et al., 2011; Hobolt, 2009; Steenbergen, Edwards, \& De Vries, 2007). In the case of this particular study, the moderating role of political information seems particularly relevant. If one does not know that Schulz is the Spitzenkandidat of the social democratic party group, ideological orientations as well as national party affiliations are not very useful devices to evaluate him. General political knowledge might be important for using national party orientations as a cue. A person with hardly any knowledge of the national parties or their ideological positions will not be able to use this information. However, an even more crucial piece of information is the party political information of the Spitzenkandidaten. Without such campaign specific information, it would be very difficult to use national party affiliations or left-right orientations as cues. From this we derive the following hypotheses:

$\mathrm{H} 2 \mathrm{~b}$ : The effect of national party affiliations (specified under $\mathrm{H} 2 \mathrm{a}$ ) will increase with the level of general political information about the EU.

$\mathrm{H} 2 \mathrm{c}$ : The effect of national party affiliations (specified under $\mathrm{H} 2 \mathrm{a}$ ) will increase with the level of campaign specific information.

H3b: The effect of left-right distances (specified under H3a) will increase with the level of general political information about the EU.

H3c: The effect of left-right distances (specified under $\mathrm{H} 3 \mathrm{a}$ ) will increase with the level of campaign specific information.

\section{Data and Methods}

\subsection{Sample and Data}

Our analysis rests on original survey data collected within a four-wave online panel study in the Netherlands between December 2013 and June 2014 in the context of the EP elections on May 22, 2014. Unlike many other online panels, respondents are not selfselected, but are based on a random sample of the Dutch adult population. It is part of the '2014 European Election Campaign Study'; and the sample is representative in terms of age, gender, and education compared to census data (De Vreese et al., 2014). The survey was conducted using Computer Assisted Web Interviewing
(CAWI), and the fieldwork was carried out by TNS NIPO Netherlands, which is a research organisation that complies with the ESOMAR guidelines for survey research approved under ISO. We employ survey questions of waves one and three. The latter contains the relevant information for our dependent variables. The fieldwork for the third wave was conducted between April 17 and 28, 2014; the first wave was fielded between December 13, 2013 and January 19, 2014. The N comprises 2189 in the first wave (response rate: 78.1\%), and 1537 in the third wave (re-contact rate: 84.5\%).

The Netherlands represents an ideal political context for studying electoral support for the Spitzenkandidaten during the 2014 European election campaigns: the three prominent Spitzenkandidaten, who are subject to this study (Jean-Claude Juncker, Martin Schulz, and Guy Verhofstadt), come from three neighbouring countries, Luxembourg, Germany, and Belgium, respectively. At the start of the campaign the party groups in the European Parliament agreed that the Spitzenkandidat of the largest party group would be nominated to become President of the Commission. This is how the debates of the Spitzenkandidaten were presented to the European public, although the heads of state in the European Council remained largely silent during the campaigns and seemingly left their options open (see also Hobolt, 2014). These developments thus represent an ideal setting for our study, which seeks to investigate whether citizens formulate a preference for an individual candidate and what explains their preferences.

\subsection{Dependent Variables and Design Issues}

Our dependent variables are electoral preferences for Spitzenkandidaten. These preferences were measured by survey questions which are intended to be as closely related as possible to electoral preferences without being contaminated by personality characteristics such as charm, friendliness, etc. These kinds of personality characteristics could themselves influence electoral preferences, but we were looking for a measure that taps into such preferences themselves. We operationalized the dependent variable by a short battery of questions, which were included in the third wave: 'The three European Party Families (the Social Democrats, the Christian Democrats, and the Liberal Democrats) have each presented a European candidate to be elected as President of the European Commission by the new Parliament. If you were able to vote for a candidate directly, how likely are you to vote for the following politicians? Please specify your views on a 10point scale where 1 means "not at all likely" and 10 means "very likely"'. Respondents were asked to indicate their probability to vote for Jean-Claude Juncker, Martin Schulz, and Guy Verhofstadt. ${ }^{5}$ The order of

${ }^{5}$ In addition, the answer options included a control, Jeroen 
these candidates was randomised. None of the respondents received information about the national or European party family affiliation of the candidates. All respondents were given a 'don't know' option. Furthermore, the sample of the third wave was split in two subsamples to which respondents were randomly assigned: under the first condition respondents were given the question as presented above $(n=789)$, respondents in the second condition ( $n=748$ ) were additionally provided with the country of origin for each candidate (e.g., 'JeanClaude Juncker from Luxembourg'). We merge both subsamples, but control for the country cue for each Spitzenkandidat with a dummy variable.

To answer our first research question, we rely on a set of binary variables which indicate whether or not respondents expressed a vote preference for each Spitzenkandidat, which is coded as 1 if they did. The majority of respondents opted for 'don't know' (coded as 0 ) on each candidate, although fewer respondents chose this option for Verhofstadt $(M=0.42, S D=0.49)$ than for Juncker $(M=0.39, S D=0.49)$ and Schulz $(M=0.39, S D=0.49)$. To explain variation in these variables we rely on a logistic regression. We analyse the preferences for each candidate separately as most respondents who indicate a preference for one candidate also indicate a preference for another candidate. Thus, modelling options such as McFadden's choice model are not appropriate, because the alternatives are not mutually exclusive.

To answer our second and third research questions, which focus on an explanation of differences in the evaluations of the three Spitzenkandidaten, we exclude the 'don't knows' on each candidate and created a dataset in a 'stacked' format. In this dataset, the respondent*candidate is the unit of analysis, so that each respondent appears as many times as there are candidates for whom $\mathrm{s} /$ he expressed a preference (maximally three times). We are primarily interested in the within-voter variation in their preferences for the three candidates (thus explaining why someone prefers candidate $A$ over $B$ ), rather than the between-voter variation (why do some people express higher preferences than others to all candidates). We therefore analyse these data by means of multi-level analyses with fixed effects at the level of individual respondents. Consequently, individual level controls which do not vary within individuals are not included in these analyses. As robustness checks, we also present random effects analyses with individual level controls in the appendix. The results are substantively very similar.

Dijsselbloem, who was Dutch Finance Minister and President of the Eurogroup at the time. Since he was not actually a standing candidate and he was always kept last in the answer options in both sub-samples, we exclude him from our analysis.

\subsection{Independent Variables}

Our main independent variables correspond to the hypotheses outlined above and are subject to both explanatory analyses. We operationalise news exposure ( $\mathrm{H} 1 \mathrm{a}$, ) by four items surveyed in the third wave. Public TV exposure $(M=3.31, S D=2.69)$ and private TV exposure $(M=2.19, S D=2.42)$ each consist of the mean number of days per week a respondent watches either a public or private news programme on television and range from 0 to 7 . For the newspaper items we aggregated the daily exposure to four broadsheets (NRC Handelsblad, NRC Next, Trouw, De Volkskrant) and four tabloids (Algemeen Dagblad, De Telegraaf, Metro, Spits), to form the variables broadsheet exposure $(M=0.99, S D=2.56)$ and tabloid exposure $(M=2.67$, $S D=3.96)$, respectively.

Political information is measured by two variables, which we operationalised in a similar manner as Nadeau et al. (2008, p. 235) and Elenbaas et al. (2012, p. 737), but with fewer and different items. The first variable, general EU information ( $\mathrm{H} 1 \mathrm{~b}, \mathrm{H} 2 \mathrm{~b}, \mathrm{H} 3 \mathrm{~b})$, is comprised of three questions from the third wave. These enquire about the number of Dutch MEPs after the 2014 elections, the current number of EU member states, and the current EP President. Each question comprised five answer categories to choose from, plus a 'don't know' option. We recoded all three variables into binary variables which are 1 if the correct answers were provided, and 0 if not. We then added them up to form a scale, ranging from 0 to $3(M=0.55, S D=0.84)$. A Mokken scale analysis (e.g., Van Schuur, 2003), which takes into account that the answer difficulty might differ across questions, reveals that these three variables can be combined into a cumulative scale. The $\mathrm{H}$ coefficient of this scale is 0.42 , which according to Mokken indicates that the items form a moderately strong scale.

We measure campaign-specific information ( $\mathrm{H} 1 \mathrm{c}$, $\mathrm{H} 2 \mathrm{c}, \mathrm{H} 3 \mathrm{c}$ ) by an additive scale of correct answers to three questions concerning the party family of the three Spitzenkandidaten under study. In the third wave respondents were asked the following: 'Several European political parties, in which Dutch political parties cooperate with other parties in Europe, have nominated a candidate for the presidency of the European Commission, should they become the largest political group in the European Parliament after the elections. Please indicate for each of the following politicians by which party they were nominated for presidency of the European Commission.' The answering options comprised six major European party groups and the respective affiliated Dutch parties, in addition to a 'don't know' and a 'none of the above' answer category. As before, correct answers were added up to form a scale that ranges from 0 to $3(M=0.28, S D=0.71)$. The Mokken scale analysis returns an $\mathrm{H}$-coefficient of 0.67 , 
indicating that the items form a very strong unidimensional scale.

The two variables campaign-specific information and general EU information are moderately correlated $(r=0.37, p<.001)$. Furthermore, bivariate correlations between the news exposure variables and the information variables are at best weak (Table A3). Correlations range from $r=0.13$ (public TV news exposure and general EU information) to $r=0.29$ (broadsheet exposure and campaign information); non-quality news exposure (including public TV and tabloids) does not have a significant relationship with the information variables. Since the correlations between the independent variables are not very strong and since we have different expectations regarding the moderating effects of the different knowledge scales, we decided that the scales should not be combined in a single measure of knowledge and/or news exposure, but that we should analyse their effects separately.

We also add the control variable national political information which comprises two questions about national politics in the third wave: one asked about the name of the current Minister of Foreign Affairs; the other one asked about the statutory length of the legislative term of the Dutch lower house. It was calculated in a similar way as the other information variables. The final variable ranges from 0 to $2(M=1.56, S D=0.65)$. The $\mathrm{H}$-coefficient $=0.58$ means that the items form a strong additive scale. Its correlations with the campaign-specific information variable is $0.21(p<.001)$; its correlation with the general EU information variable is $0.24(p<.001)$. The remaining control variables comprise age, gender (dummy female), and education (dummy variables higher and lower education, reference category: medium-level education) which were asked in the first wave.

To answer our second and third research questions, we also use general EU information as well campaign information as operationalised above. National party preferences (needed for testing $\mathrm{H} 2 \mathrm{a}, \mathrm{H} 2 \mathrm{~b}$, and $\mathrm{H} 2 \mathrm{c}$ ) were measured by asking respondents to indicate on a 10-point scale 'how likely is it that you will ever vote for this party'. In the stacked data matrix these scores were matched to the preferences for each Spitzenkandidat of the related party group: preferences for the Dutch Christian Democrats (CDA) which are part of the $\operatorname{EPP}(M=3.27, S D=2.73)$ were matched with preferences for Junker, the Labour party ( $\mathrm{PvdA})$ which belong to the S\&D $(M=3.27, S D=2.70)$ was matched to Schulz, and two liberal parties, VVD $(M=3.54, S D=2.94)$ and $D 66$ $(M=4.25, S D=2.99)$, which both form part of the ALDE group were linked to Verhofstadt. ${ }^{6}$

Finally, we measure ideological distance on the left-

\footnotetext{
${ }^{6} \mathrm{Nb} .:$ We took the means of the preferences for the VVD and D66, respectively, in order to match them to the preferences regarding Verhofstadt.
}

right scale (Left-right distance) by the absolute distance of respondents' self-placement and the respective party placements from the first wave. It ranges from 0 to $10(M=2.94, S D=2.37)$. Left-right distances to these national parties were also linked to preferences for Spitzenkandidaten in the way we just described.

To account for other potential effects, we added several controls to the main models, which are shown in the Appendix (Tables A1 and Table A4). Here we control for EU attitudes, as strong individual preferences for EU integration might matter for the extent to which respondents are willing to provide a preference for each Spitzenkandidat; and might also impact their actual preferences. Since EU attitudes are multidimensional (Boomgaarden, Schuck, Elenbaas, \& De Vreese, 2011), we use five factors which are averaged from a total of 18 survey questions from the third wave. These range from 1 ('strongly disagree') to 7 ('strongly agree'). The five factors, identified by confirmatory factor analysis, correspond to those identified by Boomgaarden et al. (2011) and De Vreese, Azrout, and Möller (2016): Negative affection $(M=3.01, S D=1.55$, Cronbach's $\alpha=0.905)$, Utilitarianism and Idealism $(M=3.76, S D=1.29, \alpha=0.856)$, Performance $(M=3.06$, $S D=1.19, \alpha=0.870)$, Identity $(M=2.73, S D=1.35, \alpha=0.863)$, and Strengthening $(M=2.81, S D=1.26, \alpha=0.723)$. A similar rationale underpins the consideration of Government satisfaction as an additional control. It is measured by the question 'The current national government is doing a good job' in the third wave with answer categories ranging from 1 ('strongly disagree') to 7 ('strongly agree'). Lastly, in the logistic regression models (Table A1), we also control for left-right selfplacement of the respondent as well as national party preferences. The descriptive statistics can be found in the appendix.

\section{Findings}

We begin our analysis by answering our first research question. Table 1 provides the logistic regression models for each of the Spitzenkandidaten Juncker, Schulz, and Verhofstadt, respectively. We report the $b$ coefficients and robust standard errors of our main effects on the dependent variable, which assesses whether citizens formulate an opinion towards each of the Spitzenkandidaten.

Our first set of hypotheses stipulates that information and news exposure can explain why some citizens express a preference for the Spitzenkandidaten. We expected that news exposure $(\mathrm{H} 1 \mathrm{a})$ would have a positive effect on citizens' propensity to express a preference for candidates. Indeed, the models show that exposure to public television and tabloids is significant for all three candidates, while broadsheet exposure only matters for the preference formation towards Schulz and Verhofstadt; the effect of private television 
Table 1. Logistic regression, predicting the likelihood to express a preference for each Spitzenkandidat.

\begin{tabular}{lcccccc}
\hline & \multicolumn{2}{c}{ Juncker } & \multicolumn{2}{c}{ Schulz } & \multicolumn{2}{c}{ Verhofstadt } \\
\cline { 2 - 6 } & $\mathbf{b}$ & SE & b & SE & b & SE \\
\hline General EU information & $0.336^{* * *}$ & 0.078 & $0.321^{* * *}$ & 0.077 & $0.314^{* * *}$ & 0.080 \\
Campaign information & $1.005^{* * *}$ & 0.144 & $0.930^{* * *}$ & 0.137 & $1.103^{* * *}$ & 0.175 \\
Public TV news exposure & $0.103^{* * *}$ & 0.026 & $0.090^{* * *}$ & 0.026 & $0.087^{* * *}$ & 0.026 \\
Private TV news exposure & 0.015 & 0.025 & 0.018 & 0.025 & -0.015 & 0.026 \\
Broadsheet exposure & 0.045 & 0.028 & $0.057^{* *}$ & 0.027 & $0.085^{* * *}$ & 0.029 \\
Tabloid exposure & $0.037^{* *}$ & 0.015 & $0.034^{* *}$ & 0.015 & $0.038^{* *}$ & 0.016 \\
Nat. political information & $0.248^{* *}$ & 0.104 & $0.261^{* *}$ & 0.103 & $0.358^{* * *}$ & 0.105 \\
Age & $0.008^{* *}$ & 0.004 & $0.009^{* *}$ & 0.004 & $0.015^{* * *}$ & 0.004 \\
Lower education & 0.234 & 0.166 & 0.192 & 0.165 & 0.131 & 0.166 \\
Higher education & $0.309^{* *}$ & 0.140 & 0.158 & 0.140 & $0.393^{* * *}$ & 0.140 \\
Female & $-0.444^{* * *}$ & 0.119 & $-0.442^{* * *}$ & 0.118 & $-0.440^{* * *}$ & 0.119 \\
Country cue & $0.318^{* * *}$ & 0.120 & $0.368^{* * *}$ & 0.119 & $0.334^{* * *}$ \\
Constant & $-2.320^{* * *}$ & 0.258 & $-2.271^{* * *}$ & 0.255 & $-2.597^{* * *}$ & 0.120 \\
\hline -2 pseudo log likelihood & 1703.254 & & 1726.720 & & 1688.578 \\
Wald chi2 & 193.953 & & 188.004 & & 194.669 \\
Prob > chi2 & 0.000 & & 0.000 & & 0.000 \\
BIC & 1798.643 & & 1822.109 & & 1783.966 \\
$\mathrm{~N}$ & 1537 & & 1537 & & 1537 \\
Pseudo R Squared & 0.170 & & 0.159 & & 0.193 \\
\hline
\end{tabular}

Note: ${ }^{*} \mathrm{p}<.1 ;{ }^{* *} \mathrm{p}<.05 ;{ }^{* * *} \mathrm{p}<.01$; dependent variable: don't know (0) vs. expressing voting preference for Spitzenkandidat (1), robust standard errors.
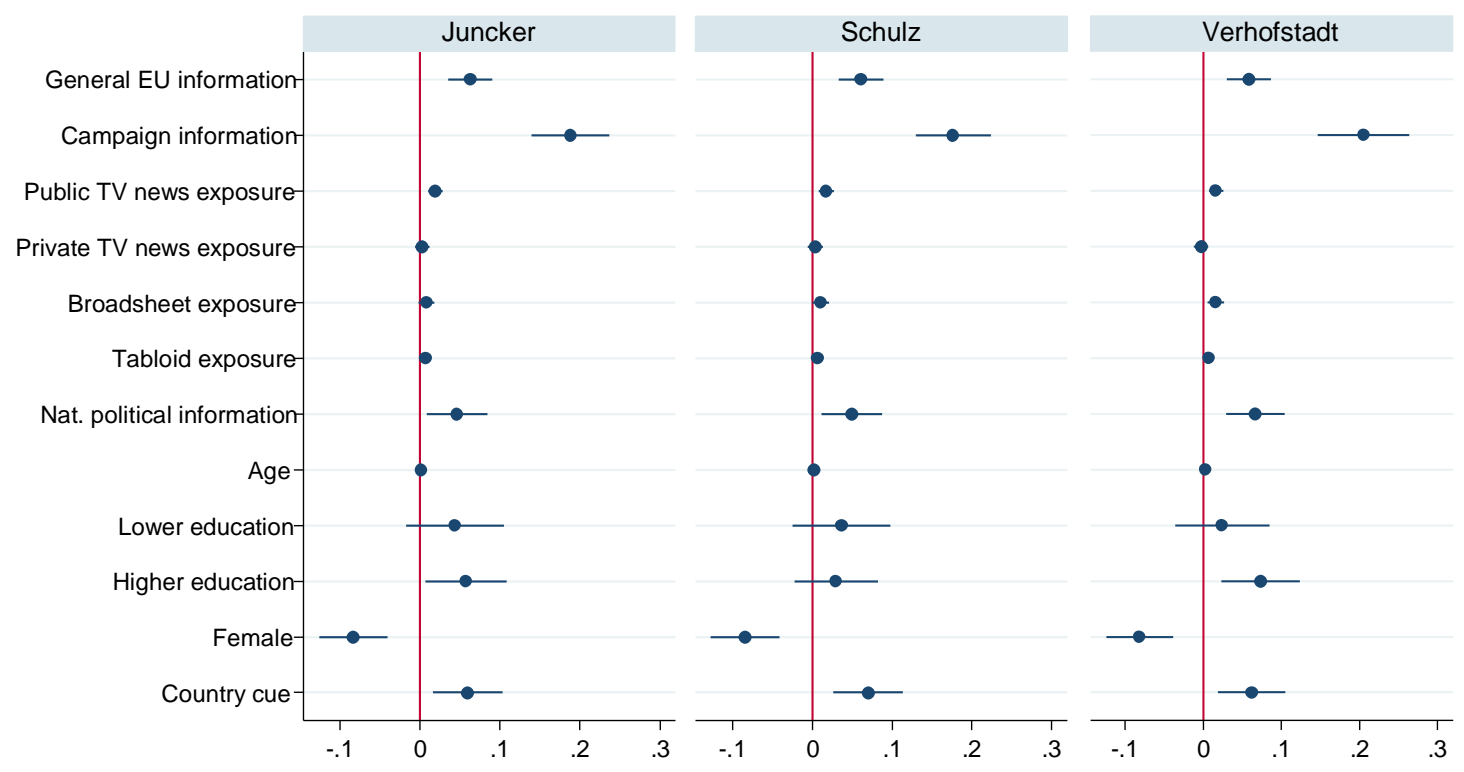

Figure 1. Average marginal effects on the likelihood to express a preference for each Spitzenkandidat. Note: calculations are based on Table 1.

is not significant. Furthermore, political information ( $\mathrm{H} 1 \mathrm{~b}$ and $\mathrm{H} 1 \mathrm{c}$ ) is a strong predictor of citizens' ability to reveal a preference for each of the Spitzenkandidaten. Table 1 shows that general information about the EU as well as campaign-specific information have significant, positive effects for all candidates.

In order to compare these effects across the Spitzenkandidaten we calculated the average marginal effects for all coefficients (see Mood, 2010). These are displayed in Figure 1. The effects of news exposure are comparatively small; exposure to public television news has the largest effect, while exposure to private television outlets has no effect for either candidate. These findings therefore only provide partial support for our first hypothesis H1a. Furthermore, Figure 1 demonstrates that the average marginal effect of campaign-specific information is strongest for all candidates, followed by the average marginal effect of gen- 
eral EU political information (and national political information). Our results therefore lend support to hypotheses $\mathrm{H} 1 \mathrm{~b}$ and $\mathrm{H} 1 \mathrm{c}$. They underline our argument that citizens are better able to formulate an opinion about the Spitzenkandidaten if they have general information about EU politics as well as campaign-specific information of the Spitzenkandidaten, given the complexity of the institutional relations in the $\mathrm{EU}$ and the abstract relationship between national parties and the nominations of the European party groups. The large effects of campaign-specific information underline that preference formation during European election campaigns is highly conditional upon the information available to citizens and voters. However, information about national politics also matters. Our control variable shows that it has a significant, positive effect for all candidates.

The effects of our control variables, higher education and age, have positive effects, although these are not consistent for all candidates. The effect of gender is significant and negative implying that men are more likely to indicate a preference for each of the Spitzenkandidaten compared to women. Furthermore, we find that, for all candidates, respondents who received a country cue opted less often for the 'don't know' response than respondents in the first group of our study.

Our next analysis seeks to answer our second and third research questions concerning the factors responsible for variation in the distribution of voter preferences for the Spitzenkandidaten, and the moderating role of political awareness in particular. Table 2 shows the results of the fixed effects regression explaining variation in voter preferences for all candidates. We are interested in the within respondent variance, not in explaining the variance between respondents. The decomposition of the variance showed that $25 \%$ of the total variance is within respondents and $75 \%$ is between. The explained variance at the within level is rather low, meaning that relevant cues, like ideology and party affiliation do not explain much of the differences in preferences.

We are interested in whether citizens base their preferences for the Spitzenkandidaten on their party preferences $(\mathrm{H} 2 \mathrm{a})$ or on their ideological proximity to the candidate's party on the left-right dimension (H3a). The results lend support to our assumptions. Model 1 shows that a one unit increase in the preference for the respective national party generates an increase of 0.15 in the preferences for the Spitzenkandidat who is supported by that party, controlling for everything else. In line with our expectations, left-right distance generates a negative effect on the dependent variable: the further away an individual voter is from the respective party stances, the lower the support for the Spitzenkandidat of that party ( $b=-0.06$, Model 4$)$. Taken together, both results suggest that citizens indeed use cues in their evaluations of the Spitzenkandidaten.

We expected further that information becomes imperative for citizens to align their preferences for the Spitzenkandidaten with their party preferences and ideological orientations. The results reported in Model 2 and 3 show that the relevance of party preferences as a cue for the preference formation for the candidates increases with higher levels of general political information about the EU $(b=0.06)$ as well as campaignspecific information $(b=0.17)$, lending support to hypotheses $\mathrm{H} 2 \mathrm{~b}$ and $\mathrm{H} 2 \mathrm{c}$, respectively.

Table 2. Fixed-effects regression, explaining variation in preferences for the Spitzenkandidaten.

\begin{tabular}{|c|c|c|c|c|c|c|}
\hline & Model 1 & Model 2 & Model 3 & Model 4 & Model 5 & Model 6 \\
\hline \multirow[t]{2}{*}{ PTV national party EU14 } & $0.152 * * *$ & $0.097 * * *$ & 0.010 & & & \\
\hline & $(0.025)$ & $(0.030)$ & $(0.024)$ & & & \\
\hline General EU information* & & $0.063^{* *}$ & & & & \\
\hline PTV national party EU14 & & $(0.026)$ & & & & \\
\hline Campaign information* & & & $0.173 * * *$ & & & \\
\hline PTV national party EU14 & & & $(0.023)$ & & & \\
\hline \multirow[t]{2}{*}{ Left-right distance } & & & & $-0.055 * *$ & -0.016 & $0.050 * *$ \\
\hline & & & & $(0.025)$ & $(0.029$ & $(0.025)$ \\
\hline General EU information* & & & & & $-0.047^{*}$ & \\
\hline Left-right distance & & & & & $(0.027)$ & \\
\hline Campaign information* & & & & & & $-0.152 * * *$ \\
\hline Left-right distance & & & & & & $(0.027)$ \\
\hline \multirow[t]{2}{*}{ Constant } & $3.370 * * *$ & $3.373 * * *$ & $3.489 * * *$ & $4.279 * * *$ & $4.277^{* * *}$ & $4.253 * * *$ \\
\hline & $(0.095)$ & $(0.094)$ & $(0.081)$ & $(0.073)$ & $(0.072)$ & $(0.067)$ \\
\hline$N$ & 1822 & 1822 & 1822 & 1600 & 1600 & 1600 \\
\hline N groups & 666 & 666 & 666 & 586 & 586 & 586 \\
\hline R Squared within & 0.052 & 0.060 & 0.126 & 0.005 & 0.009 & 0.044 \\
\hline R Squared between & 0.103 & 0.097 & 0.028 & 0.020 & 0.001 & 0.002 \\
\hline R Squared overall & 0.089 & 0.098 & 0.060 & 0.015 & 0.000 & 0.000 \\
\hline
\end{tabular}

Note: ${ }^{*} \mathrm{p}<.1 ;{ }^{*} \mathrm{p}<.05 ;{ }^{* *} \mathrm{p}<.01$; dependent variable: voting preference for a Spitzenkandidat (1-10), robust standard errors in parentheses. 
Figure 2 visualises these effects and highlights the crucial importance of information: for those who have no such information at hand, party preferences do not matter for the preference formation for the Spitzenkandidaten. It is important to realise that this is by far the largest group: two-thirds (67.9 per cent) of those respondents who evaluated the candidates (43.3 per cent) did not know the party affiliation of any candidate. However, those who are better informed positively align their party preferences with their preferences for the European lead candidates. In comparison, the interaction effects are even stronger for campaignspecific information than for general EU information. Similarly, as Table 3 ( $b=-0.05$; Model 5$)$ and Figure 2 demonstrate, the interaction effect between general EU information and left-right distance is statistically significant and thus in line with $\mathrm{H} 3 \mathrm{~b}$, yet weaker than that of campaign-specific information. Again, campaign-specific information plays a crucial role: the negative effect of the left-right distance is indeed moderated by voter knowledge about the Spitzenkandiaten $(b=-0.15$, Model 6$)$. The visualisation of this moderating effect in Figure 2 shows that, again, citizens with no campaign-specific information do not use their ideological preferences as cues in providing their preferences for the Spitzenkandidaten. Instead, their use of this cue increases with higher levels of campaign-specific information. These results thus lend support to $\mathrm{H} 3 \mathrm{C}$.
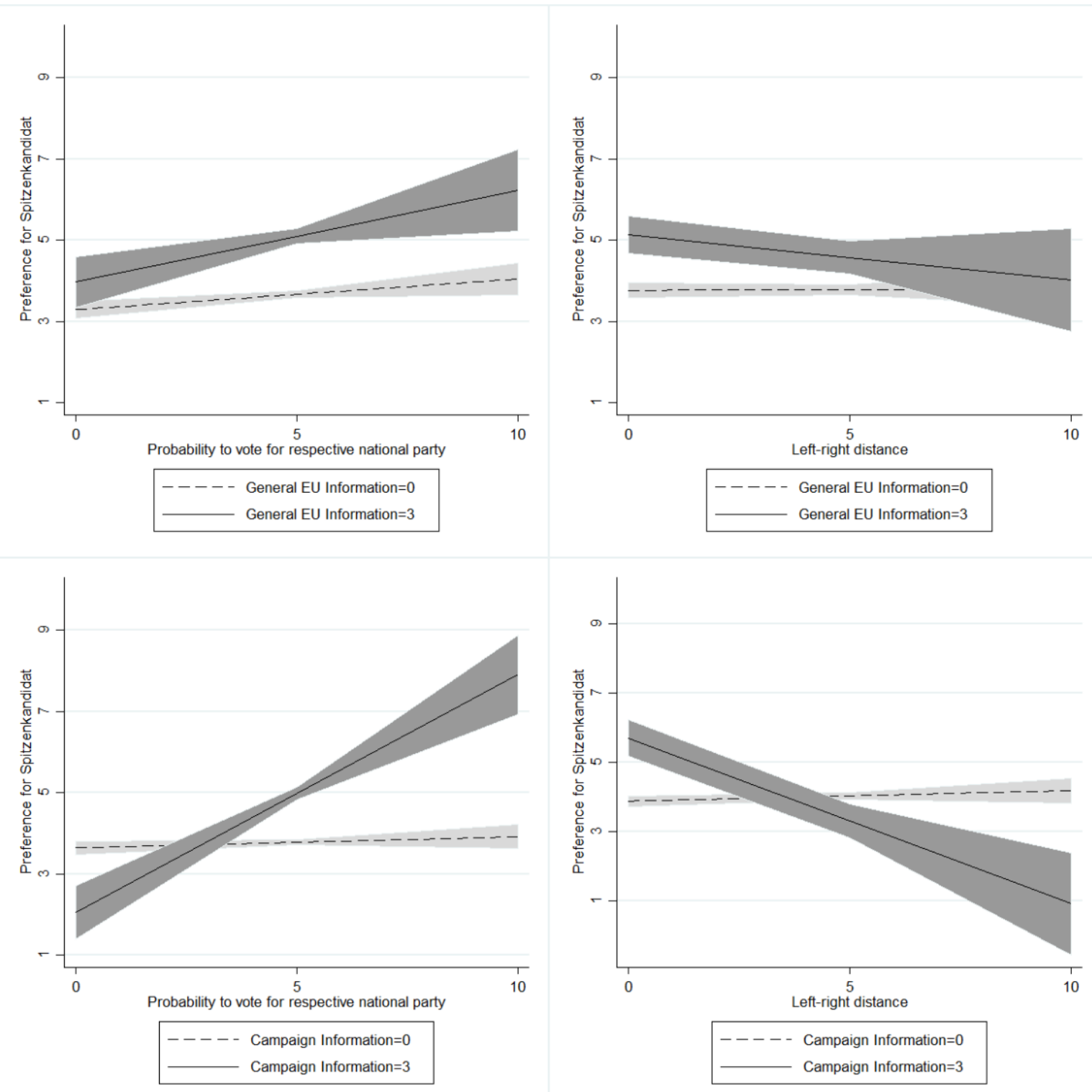

Figure 2. The effects of party preference and left-right distance on preference for a Spitzenkandidat at different levels of information. Note: lines represent expected values and shadowed areas $95 \%$ confidence intervals. The calculations are based on individual regression models testing the main effect on the dependent variable for different samples of general EU and campaign-specific information, respectively. 


\section{Conclusions}

This study set out to examine the preference formation of Dutch citizens for the Spitzenkandidaten during the 2014 EP election campaign. Our aim was two-fold: firstly, we were interested in those factors that determine whether citizens formulate a preference for a certain Spitzenkandidat. Secondly, we sought to explain the variation in their distribution of preferences. Based on the literature on citizens' preference formation, we put forward three main explanatory factors for answering the first question: news exposure as well as political information and campaign-specific information about the Spitzenkandidaten, which can be summoned under what Zaller (1992) calls political awareness. Furthermore, we argued that information also moderates the effects of national party affiliations or left-right orientations, which citizens are expected to use as cues in their evaluations of the Spitzenkandidaten.

Our results show that exposure to public television news programmes and-to some extent alsobroadsheet reading explains the likelihood of indicating a preference for the Spitzenkandidaten. These findings are in line with research that finds that exposure to quality news content or hard news has a positive effect on political participation (e.g., Aarts \& Semetko, 2003; Schmitt-Beck \& Mackenrodt, 2010). We also find a positive effect of tabloid exposure. Some literature would expect no or a negative effect of such news outlets (e.g., Aarts \& Semetko, 2003; De Vreese \& Tobiasen, 2007), but De Vreese and Boomgaarden (2006) also find that attention to tabloid newspapers has a positive effect on the intention of Dutch voters to participate in a hypothetical EU referendum (see also Banducci et al., 2015). We are unable to assess whether this is due to specific content features of this news coverage, let alone establish whether they were visible at all in these newspapers. This has to do with the timing of our study. The third wave concluded on April 28, 2014. On that day the first pan-European presidential debate took place in Maastricht, after which the visibility of the Spitzenkandidaten in national broadsheets increased considerably across Europe (Gattermann, 2015).

Furthermore, both general information about the EU and campaign-specific information represent important pre-conditions for citizens to formulate a preference for each of the Spitzenkandidaten. This resonates with research on voting behaviour and opinion formation in the EU context which underlines the importance of knowledge about European affairs (e.g., Hobolt, 2007; De Vries et al., 2011) and specific information either about party positions (Hobolt \& Wittrock, 2011) or EU performances (Elenbaas et al., 2012). We believe that in the context of the 2014 elections acquiring general political information is crucial because of the complexity of the investiture procedure; and knowledge of the Spitzenkandidaten be- comes imperative since citizens elect national parties at the polls and hence need to have information about which candidate these parties support.

Our results also confirm earlier research showing how citizens can use cues to arrive at meaningful electoral decisions (e.g., Hobolt, 2007; Lupia, 1994; Toka, 2008; Van der Brug, 1999). Even though we did not strictly study electoral decisions, our study shows that citizens can form meaningful preferences for candidates that are relatively unknown by relying upon relevant party cues. However, most of the literature studies electoral contexts in which people with little knowledge can use cues to arrive at a reasoned choice. In the current context, we found that only the most knowledgeable are able to use these cues, while those citizens who have no or only little EU political and campaign-specific information hardly use any cues of party identification or ideological orientations in their evaluations of the Spitzenkandidaten.

Given the importance of news exposure and information, only few citizens actually expressed their preferences for each Spitzenkandidat. Moreover, of the minority of respondents who evaluated the candidates, only one third knew the party affiliation of one or more of these candidates. Even if we put the bar very lowbeing able to name the party affiliation of one candidate and evaluating at least one candidate-just 16.1\% of the respondents fulfil this criterion for providing a meaningful assessment of the candidates. While this has rather negative implications for democratic participation of EU citizens in EU elections, we should be careful not to dismiss the Spitzenkandidaten campaigns right away. European elections are still second-order and as such it is no surprise that many citizens are not sufficiently informed to express their opinion. Druckman (2014, p. 478) argues that we should be persuaded of 'the need to be realistic about what to expect of citizens and avoid setting impossible bars such as "full information"' (emphasis in the original). It was the first time that European election campaigns were influenced by the Spitzenkandidaten; and the consequences of their nomination were still unknown during the campaign. Our finding that campaign-specific information is of crucial importance for citizens' ability to formulate a political preference in EU elections thus also represents a recommendation for the 2019 elections to foster the campaign environment at the European level.

Our results, which show that those citizens who are politically aware are also able to align their preferences for each Spitzenkandidat with their national party preferences as well as with their ideological orientation, underline our recommendation. To use the words of Hobolt and Tilley (2014) these citizens 'get it right'. Our analysis was based on a hypothetical question but the findings nevertheless imply that informed citizens and those who are regularly exposed to news might actually be able to hold their EU representatives accountable, 
provided they are given the opportunity to do so. Thus, depending on their intensity, the Spitzenkandidaten campaigns may be able to contribute to alleviating the EU's alleged accountability deficit.

\section{Acknowledgements}

The authors wish to thank the participants of the ACCESS EUROPE workshop on "The European Elections 2014", the panel "Voters and Parties in the EU" at the EPSA 2015 annual conference, and the European Elections Studies Jubilee Conference, as well as the anonymous reviewers for their helpful comments and suggestions. The usual disclaimer applies.

\section{Conflict of Interests}

The authors declare no conflict of interests.

\section{References}

Aarts, K., \& Semetko, H. A. (2003). The divided electorate: Media use and political involvement. Journal of Politics, 65(3), 759-784.

Alvarez, R. M. (1997). Information and elections. Ann Arbor, MI: University of Michigan Press.

Anderson, C. J. (1998). When in doubt use proxies: Attitudes to domestic politics and support for the EU. Comparative Political Studies, 31(4), 569-601.

Arcenaux, K. (2006). Do campaigns help voters learn? A cross-national analysis. British Journal of Political Science, 36(1), 159-173.

Banducci, S., Giebler, H., \& Kritzinger, S. (2015). Knowing more from less: How the information environment increases knowledge of party positions. British Journal of Political Science. doi:10.1017/S000712341 5000204

Boomgaarden, H. G., \& De Vreese, C. H. (2016). Do European elections create a European public sphere? In W. Van der Brug \& C. H. De Vreese (Eds.), (Un)intended consequences of European Parliamentary elections (pp. 19-35). Oxford: Oxford University Press.

Boomgaarden, H. G., Johann, D., \& Kritzinger, S. (2016). Voting at national versus European elections: An individual level test of the second order paradigm for the 2014 European Parliament elections. Politics and Governance, 4(1), 130-144.

Boomgaarden, H. G., Schuck, A. R. T., Elenbaas, M., \& De Vreese, C. H. (2011). Mapping EU attitudes: Conceptual and empirical dimensions of Euroscepticism and EU support. European Union Politics, 12(2), 241-266.

Boumans, J. W., Boomgaarden, H. G., \& Vliegenthart, R. (2013). Media personalisation in context: A crossnational comparison between the UK and the Netherlands, 1992-2007. Political Studies, 61(S1), 198216.
Brewer, P. R., \& Cao, X. (2006). Candidate appearances on soft news shows and public knowledge about primary campaigns. Journal of Broadcasting \& Electronic Media, 50(1), 18-35.

Campbell, A., Converse, P. E., Miller, W. E., \& Stokes, D. E. (1960). The American voter. New York, NY: John Wiley \& Sons.

Carrubba, C., \& Timpone, R. J. (2005). Explaining vote switching across first- and second-order elections: Evidence from Europe. Comparative Political Studies, 38(3), 260-281.

Chaffee, S. H., Zhao, X., \& Leshner, G. (1994). Political knowledge and the campaign media of 1992. Communication Research, 21(3), 305-324.

Clark, N., \& Rohrschneider, R. (2009). Second-order elections versus first-order thinking: How voters perceive the representation process in a multi-layered system of governance. Journal of European Integration, 31(5), 645-664.

Converse, P. A. (1962). Information flow and the stability of partisan attitudes. Public Opinion Quarterly, 26(4), 578-599

De Vreese, C. H., Azrout, R., \& Möller, J. (2014). 2014 European Parliament election campaign study: Data and documentation. Amsterdam: University of Amsterdam

De Vreese, C. H., Azrout, R., \& Möller, J. (2016). Cross road elections: Dimensions of EU attitudes and the European Parliament elections 2014. Politics and Governance, 4(1), 69-82.

De Vreese, C. H., Banducci, S. A., Semetko, H. A., \& Boomgaarden, H. G. (2006). The news coverage of the 2004 European parliamentary election campaign in 25 countries. European Union Politics, 7(4), 477 504.

De Vreese, C. H., \& Boomgaarden, H. G. (2006). News, political knowledge and participation: The differential effects of news media exposure on political knowledge and participation. Acta Politica, 41(4), 317-341.

De Vreese, C. H., \& Tobiasen, M. (2007). Conflict and identity: Explaining turnout and anti-integrationist voting in the Danish 2004 elections for the European Parliament. Scandinavian Political Studies, 30(1), 87114.

De Vries, C. E. (2007). Sleeping giant: Fact or fairytale? How European integration affects vote choice in national elections. European Union Politics, 8(3), 363385.

De Vries, C. E., Van der Brug, W., Van Egmond, M. H., \& Van der Eijk, C. (2011). Individual and contextual variation in EU issue voting: The role of political information. Electoral Studies, 30(1), 16-28.

Delli Carpini, M., \& Keeter, S. (1996). What Americans know about politics and why it matters. New Haven, CT: Yale University Press.

Downs, A. (1957). An economic theory of democracy. 
New York: Harper.

Druckman, J. N. (2014). Pathologies of studying public opinion, political communication, and democratic responsiveness. Political Communication, 31(3), 467492.

Elenbaas, M., De Vreese, C. H., Boomgaarden, H. G., \& Schuck, A. R. T. (2012). The impact of information acquisition on EU performance judgements. European Journal of Political Research, 51(6), 728-755.

Føllesdal, A., \& Hix, S. (2006). Why there is a democratic deficit in the EU: A response to Majone and Moravcsik, Journal of Common Market Studies, 44(3), 533562.

Gattermann, K. (2013). News about the European Parliament: Patterns and external drivers of broadsheet coverage. European Union Politics, 14(3), 436-457.

Gattermann, K. (2015). Europäische Spitzenkandidaten und deren (Un-) Sichtbarkeit in der nationalen Zeitungsberichterstattung. In M. Kaeding \& N. Switek (Eds.), Die Europawahl 2014 (pp. 211-222). Wiesbaden: Springer VS.

Gattermann, K., \& Vasilopoulou, S. (2015). Absent yet popular? Explaining news visibility of Members of the European Parliament. European Journal of Political Research, 54(1), 121-140.

Gelman, A., \& King, G. (1993). Why are American presidential election campaign polls so variable when votes are so predictable? British Journal of Political Science, 23(4), 409-451.

Giebler, H., \& Wagner, A. (2015). Contrasting first- and second-order electoral behaviour: Determinants of individual party choice in European and German federal elections. German Politics, 24(1), 46-66.

Hix, S., \& Marsh, M. (2011). Second-order effects plus pan-European political swings: An analysis of European Parliament elections across time. Electoral Studies, 30(1), 4-15.

Hobolt, S. B. (2007). Taking cues on Europe? Voter competence and party endorsements in referendums on European integration. European Journal of Political Research, 46(2), 151-182.

Hobolt, S. B. (2009). Europe in question: Referendums on European integration. Oxford: Oxford University Press.

Hobolt, S. B. (2014). A vote for the President? The role of Spitzenkandidaten in the 2014 European Parliament elections. Journal of European Public Policy, 21(10), 1528-1540.

Hobolt, S. B., \& Tilley, J. (2014). Blaming Europe? Responsibility without accountability in the European Union. Oxford: Oxford University Press.

Hobolt, S. B., \& Wittrock, J (2011). The second-order election model revisited: An experimental test of vote choices in European Parliament elections. Electoral Studies, 30(1), 29-40.

Jebril, N., Albæk, E., \& De Vreese, C. H. (2013). Infotainment, cynicism and democracy: The effects of privat- ization vs personalization in the news. European Journal of Communication, 28(2),105-121.

Langer, A. I. (2007). A historical exploration of the personalisation of politics in the print media: The British Prime Ministers (1945-1999). Parliamentary Affairs, 60(3), 371-387.

Lau, R. R., \& Redlawsk, D. P. (2001). Advantages and disadvantages of cognitive heuristics in political decision making. American Journal of Political Science, 45(4), 951-971.

Lodge, M., Steenbergen, M. R., \& Brau, S. (1995). The responsive voter: Campaign information and the dynamics of candidate evaluation. American Political Science Review, 89(2), 309-326.

Lupia, A. (1994). Shortcuts versus encyclopedias: Information and voting behavior in California insurance reform elections. American Political Science Review, 88(1), 63-76.

Maier, J., Rittberger, B., \& Faas, T. (2016). Debating Europe. Effects of the "Eurovision Debate" on EU attitudes of young German voters and the moderating role played by political involvement. Politics and Governance, 4(1), 55-68.

Mood, C. (2010). Logistic regression: Why we cannot do what we think we can do, and what we can do about it, European Sociological Review, 26(1), 67-82.

Nadeau, R., Nevitte, N., Gidengil, E., \& Blais, A. (2008). Election campaigns as information campaigns: Who learns what and does it matter? Political Communication, 25(3), 229-248.

Popkin, S. L. (1991). The reasoning voter: Communication and persuasion in presidential campaigns. Chicago: The University of Chicago Press.

Put, G.-J., Van Hecke, S., Cunningham, C., \& Wolfs, W. (2016). The choice of Spitzenkandidaten: A comparative analysis of the Europarties' selection procedures. Politics and Governance, 4(1), 9-22.

Rahat, G., \& Sheafer, T. (2007). The personalization(s) of politics: Israel, 1949-2003. Political Communication, 24(1), 65-80.

Reif, K., \& Schmitt, H. (1980). Nine second order national elections: A conceptual framework for the analysis of European election results. European Journal of Political Research, 8(1), 3-44.

Schmitt, H., Hobolt, S. B., \& Popa, S. A. (2015). Does personalization increase turnout? Spitzenkandidaten in the 2014 European Parliament elections, European Union Politics, 16(3), 347-368.

Schmitt, H., \& J. Thomassen. (1999). Political representation and legitimacy in the European Union. Oxford: Oxford University Press.

Schmitt-Beck, R., \& Mackenrodt, C. (2010) Social networks and mass media as mobilizers and demobilizers: A study of turnout at a German local election. Electoral Studies, 29(3), 392-404.

Schuck, A. R. T., Vliegenthart, R., \& De Vreese, C. H. (2016). Who's afraid of conflict? The mobilizing ef- 
fect of conflict framing in campaign news. British Journal of Political Science, 46(1), 177-194.

Schuck, A. R. T., Xezonakis, G., Elenbaas, M., Banducci, S. A., \& De Vreese, C. H. (2011). Party contestation and Europe on the news agenda: The 2009 European parliamentary elections. Electoral Studies, 30(1), 41-52.

Schulze, H. (2016). The Spitzenkandidaten in the European Parliament election campaign coverage 2014 in Germany, France, and the United Kingdom. Politics and Governance, 4(1), 23-36.

Sniderman, P. M. (2000). Taking sides: A fixed choice theory of political reasoning. In A. Lupia, M. D. McCubbins \& S. L. Popkin (Eds.), Elements of reason: Cognition, choice and the bounds of rationality. Cambridge: Cambridge University Press.

Steenbergen, M. R., Edwards, E. E., \& De Vries, C. E. (2007). Who's cueing whom? Mass-elite linkages and the future of European integration. European Union Politics, 8(1), 13-35.

Toka, G. (2008). Citizen information, election outcomes and good governance. Electoral Studies, 27(1), 31-44. Van der Brug, W. (1999). Voters' perceptions and party dynamics. Party Politics, 5(2), 147-169.

Van der Brug, W., \& Van der Eijk, C. (2007). European elections and domestic politics: Lessons from the past and scenarios for the future. Notre Dame, IN: University of Notre Dame Press.

Van der Eijk, C. \& Franklin, M. N. (Eds.). (1996). Choosing Europe? The European electorate and national politics in the face of the Union. Ann Arbor: University of Michigan Press.

Van der Eijk, C., Franklin, M., \& Marsh, M. (1996). What voters teach us about Europe-wide Elections; What Europe-wide elections teach us about voters. Electoral Studies, 15(2), 149-166.

Van Schuur, W. H. (2003). Mokken scale analysis: Between the Guttman scale and parametric item response theory. Political Analysis, 11(2), 139-163.

Zaller, J. (1992). The nature and origins of mass opinion. Cambridge: Cambridge University Press.

\section{About the Authors}

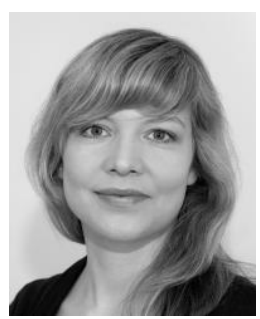

\section{Dr. Katjana Gattermann}

Katjana Gattermann is assistant professor of political communication and journalism at AScoR and also affiliated with ACCESS EUROPE at the University of Amsterdam. She is founding director of the Erasmus Academic Network on Parliamentary Democracy in Europe (PADEMIA). Her research interests comprise political communication, political behaviour, public opinion and legislative behaviour in the EU. Her work has appeared in journals such as the European Journal of Political Research, European Union Politics, and West European Politics.

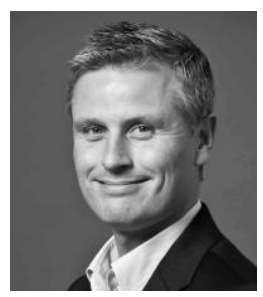

\section{Prof. Dr. Claes de Vreese}

Claes de Vreese is Professor and Chair of Political Communication at ASCoR at the University of Amsterdam. He is the founding Director of Center for Politics and Communication (www.polcomm.org). His research interests focus on political journalism, media effects, public opinion and electoral behaviour. His most recent (co-authored) books are Political Journalism in Comparative Perspective (Cambridge UP) and (Un)intended Consequences of European Parliament Elections (Oxford UP).

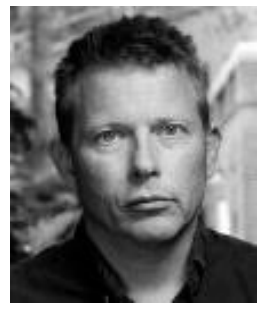

\section{Prof. Dr. Wouter van der Brug}

Wouter van der Brug is Professor and Chair of Political Science at the University of Amsterdam. His research interests focus on comparative research in collective political behaviour, in particular electoral behaviour, right-wing populism, political trust and support and political parties. He publishes regularly in various international Political Science journals. His most recent (co-authored/co-edited) books are The Politicisation of Migration (2015, Routledge) and (Un)intended Consequences of European Parliament Elections (2016, Oxford UP). 


\section{Appendix}

Table A1. Logistic regression, predicting the likelihood to express a preference for each Spitzenkandidat (full model).

\begin{tabular}{|c|c|c|c|c|c|c|}
\hline & \multicolumn{2}{|c|}{ Juncker } & \multicolumn{2}{|c|}{ Schulz } & \multicolumn{2}{|c|}{ Verhofstadt } \\
\hline & b & SE & b & SE & b & SE \\
\hline General EU information & $0.333 * * *$ & 0.083 & $0.324 * * *$ & 0.081 & $0.311^{* * *}$ & 0.085 \\
\hline Campaign information & $0.956 * * *$ & 0.148 & $0.872 * * *$ & 0.141 & $1.031^{* * *}$ & 0.177 \\
\hline Public TV news exposure & $0.128 * * *$ & 0.029 & $0.112 * * *$ & 0.028 & $0.107 * * *$ & 0.028 \\
\hline Private TV news exposure & 0.014 & 0.029 & 0.022 & 0.028 & -0.011 & 0.029 \\
\hline Broadsheet exposure & $0.053^{*}$ & 0.028 & $0.063 * *$ & 0.028 & $0.093 * * *$ & 0.030 \\
\hline Tabloid exposure & $0.032 *$ & 0.018 & 0.027 & 0.018 & $0.032 *$ & 0.018 \\
\hline Negative affection & 0.080 & 0.053 & $0.096^{*}$ & 0.053 & $0.090 *$ & 0.054 \\
\hline Performance & $0.166^{* *}$ & 0.082 & 0.132 & 0.083 & 0.068 & 0.081 \\
\hline Identity & -0.012 & 0.068 & 0.001 & 0.069 & -0.005 & 0.07 \\
\hline Utilitarianism/idealism & 0.005 & 0.083 & 0.013 & 0.082 & 0.062 & 0.081 \\
\hline Strengthening & -0.008 & 0.068 & 0.003 & 0.067 & 0.002 & 0.068 \\
\hline PTV CDA EU14 & 0.002 & 0.026 & 0.001 & 0.026 & 0.001 & 0.026 \\
\hline PTV PvdA EU14 & 0.018 & 0.030 & 0.013 & 0.029 & 0.006 & 0.030 \\
\hline PTV VVD EU14 & 0.027 & 0.028 & 0.024 & 0.028 & 0.029 & 0.029 \\
\hline PTV D66 EU14 & -0.024 & 0.026 & -0.021 & 0.026 & -0.005 & 0.026 \\
\hline Nat. political information & $0.207^{*}$ & 0.125 & $0.204 *$ & 0.122 & $0.286 * *$ & 0.124 \\
\hline Left-right self-placement & 0.027 & 0.036 & 0.011 & 0.035 & 0.013 & 0.036 \\
\hline Government satisfaction & $-0.124 * *$ & 0.057 & $-0.099 *$ & 0.057 & -0.075 & 0.056 \\
\hline Age & 0.007 & 0.005 & $0.008^{*}$ & 0.005 & $0.015^{* * *}$ & 0.005 \\
\hline Lower education & 0.146 & 0.192 & 0.131 & 0.19 & 0.070 & 0.191 \\
\hline Higher education & $0.264^{*}$ & 0.154 & 0.116 & 0.155 & $0.342 * *$ & 0.155 \\
\hline Female & $-0.534 * * *$ & 0.131 & $-0.523 * * *$ & 0.13 & $-0.504 * * *$ & 0.132 \\
\hline Country cue & $0.312 * *$ & 0.132 & $0.381 * * *$ & 0.131 & $0.378 * * *$ & 0.132 \\
\hline Constant & $-2.630 * * *$ & 0.496 & $-2.584 * * *$ & 0.492 & $-3.052 * * *$ & 0.507 \\
\hline -2 pseudo log likelihood & 1405.184 & & 1428.816 & & 1392.45 & \\
\hline Wald chi2 & 166.628 & & 159.652 & & 162.136 & \\
\hline Prob > chi2 & 0.000 & & 0.000 & & 0.000 & \\
\hline $\mathrm{BIC}$ & 1576.249 & & 1599.881 & & 1563.515 & \\
\hline $\mathrm{N}$ & 1246 & & 1246 & & 1246 & \\
\hline Pseudo R Squared & 0.173 & & 0.160 & & 0.191 & \\
\hline
\end{tabular}

Note: ${ }^{*} \mathrm{p}<.1 ;{ }^{* *} \mathrm{p}<.05 ;{ }^{* * *} \mathrm{p}<.01$; dependent variable: don't know (0) vs. expressing voting preference for Spitzenkandidat (1), robust standard errors. 
Table A2. Descriptive statistics for full sample of the third wave (corresponding to the analysis reported in Table 1 and Table A1, respectively).

\begin{tabular}{|c|c|c|c|c|c|}
\hline Variable & $\mathbf{N}$ & Min & Max & Mean & SD \\
\hline DV Juncker & 1537 & 0.00 & 1.00 & 0.3871 & 0.48725 \\
\hline DV Schulz & 1537 & 0.00 & 1.00 & 0.3878 & 0.48740 \\
\hline DV Verhofstadt & 1537 & 0.00 & 1.00 & 0.4203 & 0.49377 \\
\hline General EU information & 1537 & 0.00 & 3.00 & 0.5504 & 0.83866 \\
\hline Campaign information & 1537 & 0.00 & 3.00 & 0.2785 & 0.71024 \\
\hline Public TV news exposure & 1537 & 0.00 & 7.00 & 3.3071 & 2.68860 \\
\hline Private TV news exposure & 1537 & 0.00 & 7.00 & 2.1932 & 2.42432 \\
\hline Broadsheet exposure & 1537 & 0.00 & 18.00 & 0.9948 & 2.56351 \\
\hline Tabloid exposure & 1537 & 0.00 & 28.00 & 2.6701 & 3.96237 \\
\hline Negative affection & 1537 & 1.00 & 7.00 & 3.0073 & 1.55186 \\
\hline Performance & 1537 & 1.00 & 7.00 & 3.0568 & 1.19464 \\
\hline Identity & 1537 & 1.00 & 7.00 & 2.7274 & 1.35066 \\
\hline Utilitarianism/idealism & 1537 & 1.00 & 7.00 & 3.7642 & 1.28594 \\
\hline Strengthening & 1537 & 1.00 & 7.00 & 2.8124 & 1.25601 \\
\hline PTV CDA EU14 & 1447 & 1 & 10 & 3.27 & 2.726 \\
\hline PTV PvdA EU14 & 1441 & 1 & 10 & 3.27 & 2.701 \\
\hline PTV VVD EU14 & 1441 & 1 & 10 & 3.54 & 2.938 \\
\hline PTV D66 EU14 & 1441 & 1 & 10 & 4.25 & 2.993 \\
\hline Nat. political information & 1537 & 0.00 & 2.00 & 1.5615 & 0.65274 \\
\hline Left-right self-placement & 1306 & 0 & 10 & 5.24 & 2.298 \\
\hline Government satisfaction & 1537 & 1 & 7 & 3.22 & 1.457 \\
\hline Age & 1537 & 18 & 92 & 48.95 & 17.168 \\
\hline Lower education & 1537 & 0.00 & 1.00 & 0.1698 & 0.37559 \\
\hline Higher education & 1537 & 0.00 & 1.00 & 0.3208 & 0.46692 \\
\hline Female & 1537 & 0.00 & 1.00 & 0.5075 & 0.50011 \\
\hline Country cue & 1537 & 0.00 & 1.00 & 0.4867 & 0.49998 \\
\hline
\end{tabular}

Table A3. Bivariate Correlations between the main independent variables.

\begin{tabular}{lccccc}
\hline & $\begin{array}{c}\text { General EU } \\
\text { information }\end{array}$ & $\begin{array}{c}\text { Campaign } \\
\text { information }\end{array}$ & $\begin{array}{c}\text { Public TV news Private TV news } \\
\text { exposure }\end{array}$ & $\begin{array}{c}\text { Broadsheet } \\
\text { exposure }\end{array}$ & $\begin{array}{c}\text { Tabloid } \\
\text { exposure }\end{array}$ \\
\hline exposure
\end{tabular}

Note: ${ }^{*} p<.1 ; * * p<.05 ; * * * p<.01$ 
Table A4. Random-effects regression, explaining variation in preferences for the Spitzenkandidaten.

\begin{tabular}{|c|c|c|c|c|c|c|c|c|c|c|c|c|}
\hline & \multicolumn{2}{|c|}{ Model 1} & \multicolumn{2}{|c|}{ Model 2} & \multicolumn{2}{|c|}{ Model 3} & \multicolumn{2}{|c|}{ Model 4} & \multicolumn{2}{|c|}{ Model 5} & \multicolumn{2}{|c|}{ Model 6} \\
\hline & b & SE & b & SE & b & SE & b & SE & b & SE & b & SE \\
\hline General EU information & $0.242 * * *$ & 0.090 & 0.053 & 0.132 & $0.252 * * *$ & 0.091 & $0.224^{* *}$ & 0.094 & $0.335^{* * *}$ & 0.109 & $0.207^{* *}$ & 0.094 \\
\hline Campaign information & -0.075 & 0.090 & -0.074 & 0.090 & $-0.657 * * *$ & 0.132 & -0.056 & 0.092 & -0.059 & 0.092 & $0.341 * * *$ & 0.111 \\
\hline Public TV news exposure & $0.101 * * *$ & 0.035 & $0.102 * * *$ & 0.035 & $0.095 * * *$ & 0.035 & $0.102 * * *$ & 0.038 & $0.099 * * *$ & 0.038 & $0.099 * * *$ & 0.038 \\
\hline Private TV news exposure & 0.011 & 0.034 & 0.014 & 0.034 & 0.009 & 0.034 & 0.01 & 0.036 & 0.011 & 0.036 & 0.011 & 0.036 \\
\hline Broadsheet exposure & 0.013 & 0.023 & 0.014 & 0.023 & 0.010 & 0.023 & 0.003 & 0.023 & 0.001 & 0.023 & 0.001 & 0.023 \\
\hline Tabloid exposure & 0.032 & 0.020 & 0.030 & 0.02 & $0.034^{*}$ & 0.020 & 0.028 & 0.021 & 0.029 & 0.021 & 0.030 & 0.021 \\
\hline PTV national party EU14 & $0.160 * * *$ & 0.023 & $0.118^{* * *}$ & 0.027 & $0.047 * *$ & 0.022 & & & & & & \\
\hline $\begin{array}{l}\text { General EU information* PTV } \\
\text { national party EU14 }\end{array}$ & & & $0.049 * *$ & 0.023 & & & & & & & & \\
\hline $\begin{array}{l}\text { Campaign information* PTV } \\
\text { national party EU14 }\end{array}$ & & & & & $0.147^{* * *}$ & 0.022 & & & & & & \\
\hline Left-right distance & & & & & & & $-0.060 * * *$ & 0.023 & -0.028 & 0.027 & 0.031 & 0.024 \\
\hline $\begin{array}{l}\text { General EU information* Left- } \\
\text { right distance }\end{array}$ & & & & & & & & & -0.040 & 0.025 & & \\
\hline $\begin{array}{l}\text { Campaign information* Left- } \\
\text { right distance }\end{array}$ & & & & & & & & & & & $-0.136 * * *$ & 0.025 \\
\hline Negative affection & 0.031 & 0.060 & 0.034 & 0.060 & 0.041 & 0.061 & 0.072 & 0.070 & 0.073 & 0.070 & 0.077 & 0.070 \\
\hline Performance & 0.163 & 0.101 & $0.170^{*}$ & 0.100 & $0.182^{*}$ & 0.102 & $0.197^{*}$ & 0.108 & $0.201^{*}$ & 0.109 & $0.227^{* *}$ & 0.109 \\
\hline Identity & $0.289 * * *$ & 0.081 & $0.290 * * *$ & 0.081 & $0.281 * * *$ & 0.081 & $0.270 * * *$ & 0.091 & $0.270 * * *$ & 0.091 & $0.271 * * *$ & 0.091 \\
\hline $\begin{array}{l}\text { Utilitarianism/ } \\
\text { idealism }\end{array}$ & 0.137 & 0.095 & 0.133 & 0.095 & 0.145 & 0.096 & $0.228^{* *}$ & 0.105 & $0.228^{* *}$ & 0.106 & $0.214^{* *}$ & 0.106 \\
\hline Strengthening & 0.018 & 0.078 & 0.017 & 0.078 & 0.021 & 0.078 & 0.023 & 0.085 & 0.026 & 0.085 & 0.028 & 0.084 \\
\hline Nat. political information & 0.109 & 0.160 & 0.122 & 0.161 & 0.136 & 0.164 & -0.146 & 0.204 & -0.145 & 0.204 & -0.127 & 0.204 \\
\hline Government satisfaction & 0.08 & 0.067 & 0.082 & 0.067 & 0.092 & 0.068 & 0.11 & 0.072 & 0.110 & 0.072 & 0.113 & 0.072 \\
\hline Age & 0.007 & 0.005 & 0.007 & 0.005 & 0.008 & 0.005 & 0.004 & 0.072 & 0.005 & 0.006 & 0.004 & 0.006 \\
\hline Lower education & -0.068 & 0.233 & -0.09 & 0.234 & -0.100 & 0.234 & -0.086 & 0.259 & -0.102 & 0.260 & -0.127 & 0.260 \\
\hline Higher education & $0.373^{* *}$ & 0.181 & $0.361^{* *}$ & 0.183 & $0.423^{* *}$ & 0.184 & $0.448^{* *}$ & 0.197 & $0.448^{* *}$ & 0.197 & $0.437^{* *}$ & 0.197 \\
\hline Female & 0.100 & 0.161 & 0.114 & 0.161 & 0.140 & 0.164 & 0.217 & 0.175 & 0.221 & 0.176 & 0.228 & 0.176 \\
\hline Country cue & $0.266^{*}$ & 0.156 & $0.276^{*}$ & 0.157 & $0.283^{*}$ & 0.158 & 0.263 & 0.170 & 0.265 & 0.170 & 0.260 & 0.171 \\
\hline Constant & -0.460 & 0.576 & -0.369 & 0.583 & -0.283 & 0.588 & 0.271 & 0.730 & 0.156 & 0.730 & -0.065 & 0.726 \\
\hline $\mathrm{N}$ & 1822 & & 1822 & & 1822 & & 1600 & & 1600 & & 1600 & \\
\hline N groups & 666 & & 666 & & 666 & & 586 & & 586 & & 586 & \\
\hline R Squared within & 0.052 & & 0.060 & & 0.124 & & 0.005 & & 0.008 & & 0.044 & \\
\hline R Squared between & 0.255 & & 0.252 & & 0.239 & & 0.215 & & 0.214 & & 0.211 & \\
\hline R Squared overall & 0.214 & & 0.214 & & 0.220 & & 0.164 & & 0.165 & & 0.171 & \\
\hline
\end{tabular}

Note: ${ }^{*} \mathrm{p}<.1 ;{ }^{* *} \mathrm{p}<.05 ;{ }^{* *} \mathrm{p}<.01$; dependent variable: voting preference for a Spitzenkandidat (1-10), robust standard error. 
Table A5. Descriptive statistics corresponding to the analysis reported in Tables 2 and A4.

\begin{tabular}{lccccc}
\hline Variable & $\mathbf{N}$ & Min & Max & Mean & SD \\
\hline PTV for Spitzenkandidat (DV) & 1837 & 1.00 & 10.00 & 3.9358 & 2.61848 \\
General EU information & 1837 & 0.00 & 3.00 & 0.8029 & 0.96244 \\
Campaign information & 1837 & 0.00 & 3.00 & 0.5890 & 0.95734 \\
Public TV news exposure & 1837 & 0.00 & 7.00 & 4.1306 & 2.65096 \\
Private TV news exposure & 1837 & 0.00 & 7.00 & 2.2444 & 2.49763 \\
Broadsheet exposure & 1837 & 0.00 & 18.00 & 1.6298 & 3.23720 \\
Tabloid exposure & 1837 & 0.00 & 21.00 & 3.1840 & 4.11476 \\
Negative affection & 1837 & 1.00 & 7.00 & 2.9477 & 1.64205 \\
Performance & 1837 & 1.00 & 7.00 & 3.0912 & 1.23614 \\
Identity & 1837 & 1.00 & 7.00 & 2.8173 & 1.46452 \\
Utilitarianism/idealism & 1837 & 1.00 & 7.00 & 3.9469 & 1.39354 \\
Strengthening & 1837 & 1.00 & 7.00 & 2.8848 & 1.39242 \\
PTV national party EU14 & 1800 & 1.00 & 10.00 & 3.64 & 2.688 \\
Nat. political information & 1837 & 0.00 & 2.00 & 1.7349 & 0.54428 \\
Left-right distance & 1600 & 0.00 & 10.00 & 2.9384 & 2.37030 \\
Government satisfaction & 1837 & 1.00 & 7.00 & 3.26 & 1.533 \\
Age & 1837 & 18 & 87 & 53.60 & 16.722 \\
Lower education & 1837 & 0.00 & 1.00 & 0.1590 & 0.36573 \\
Higher education & 1837 & 0.00 & 1.00 & 0.3941 & 0.48879 \\
Female & 1837 & 0.00 & 1.00 & 0.4241 & 0.49433 \\
Country cue & 1837 & 0.00 & 1.00 & 0.5161 & 0.49988 \\
\hline
\end{tabular}

